\title{
Institutionalized Hypocrisy: Sex, Money and Law
}

J ACEK MARIA KURCZEWSKI*

Kurczewski, J.M., 2018. Institutionalized Hypocrisy: Sex, Money and Law. Oñati Socio-legal Series [online], 8 (8), 1151-1163. Received: 12-11-2018; Accepted: 05-12-2018. Available from: https://doi.org/10.35295/osls.iisl/0000-0000-0000-0987

\begin{abstract}
This paper draws on analysis by social historians ranging from the late Middle Ages and Renaissance in France to recent administrative history in Poland to illustrate basic contradictions in Western thought about sexuality. These have resulted over time in policies which range from prohibition of sex work to tolerance of the need to meet physical needs accompanied by an appreciation of the financial profits to be obtained by the state as well as the individual, combined with abhorrence of female adultery. The paper closes with original data on current public attitudes towards the impact on reputation of a range of behaviours in Poland, including sexual activities, and finds a high level of agreement about the damaging impact on reputation of not sexwork itself but of living off the proceeds of sexwork.
\end{abstract}

\section{Key words}

Sexwork; legal regulation; public attitudes to sexwork in Poland; profiting from sexwork

\section{Resumen}

Este artículo se basa en los análisis de historiadores sociales de Francia de finales de la Edad Media y el Renacimiento, así como en la historia administrativa reciente de Polonia, para ilustrar contradicciones básicas en el pensamiento occidental sobre la sexualidad. Éstas, a lo largo del tiempo, han producido políticas que van desde prohibir el trabajo sexual hasta tolerar la satisfacción de necesidades físicas, acompañado por el aprecio de los beneficios económicos que obtienen el Estado y los individuos, combinado con la repulsa al adulterio femenino. El artículo se cierra con datos originales sobre actitudes públicas contemporáneas en Polonia sobre el impacto en la reputación de una serie de comportamientos, y halla una gran unanimidad sobre

\footnotetext{
* Professor Jacek Kurczewski is Chair of Sociology and Anthropology of Custom and Law, Institute of Applied Social Sciences, University of Warsaw. He trained as a sociologist and his main areas of interest are sociology and anthropology of law, political representation, local-level politics. In 1997/98 he was elected as Academic Director, International Institute for the Sociology of Law, Oñati, Spain. He is editor of Societas/Communitas. Among other monographs in English, he has published Living Sociology of Law (Warsaw, 2010) and Resurrection of Rights in Poland (Oxford, 1993), and in Polish Paths of Emancipation (2009). He has co-edited in English (with J. Arcimowicz) Dependence or Cooperation? Dialectics of Official Practices (Warsaw 2011); (with M.Maclean) Family Law and Family Policy in New Europe (Aldershot 1997) and Families, Politics, and Law in West and East (Oxford 1994). He was advisor to Solidarność (1981-) and to Lech Wałesa (1988-1991), is a former MP (1991-3), 1993-2000 and is member of the Programme Council of Polish Public Television. Contact details: Krakowskie Przedmieście 26/28, 00-927 Warsaw, Poland. Email address: j.kurczewski@isns.uw.edu.pl ORCID: https://orcid.org/0000-0003-2889-6120
}

\section{(cc) EY-NC-ND}

Oñati International Institute for the Sociology of Law 
el impacto negativo, no del trabajo sexual en sí, sino de vivir del producto del trabajo sexual.

\section{Palabras clave}

Trabajo sexual; regulación jurídica; actitudes públicas hacia el trabajo sexual en Polonia; beneficiarse del trabajo sexual 


\section{Table of contents / Índice}

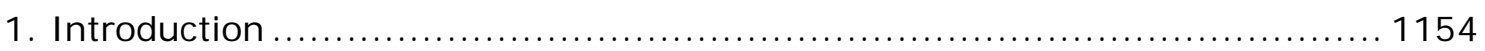

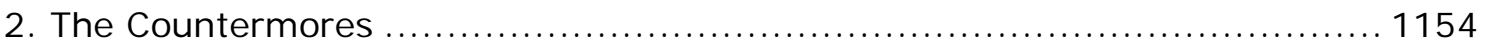

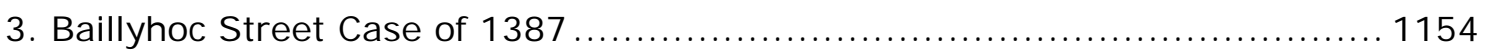

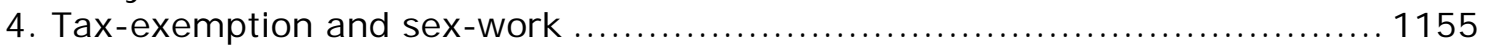

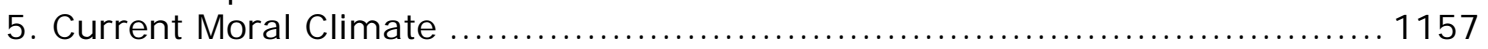

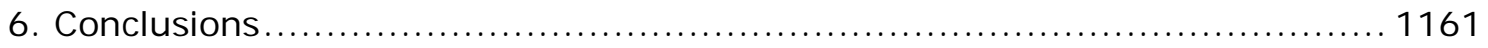

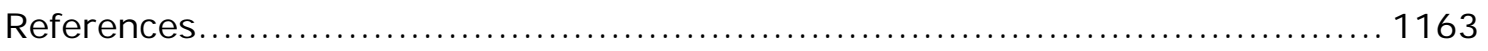


In memory of Bronislaw Geremek (1938-2008), Polish and European statesman and renowned scholar of medieval Paris, including the sexwork

[T] hose who are in authority, rightly tolerate certain evils, lest certain goods be lost, or certain greater evils be incurred;" thus Augustine says. (De Ordine ii: 4)

If you do away with harlots, the world will be convulsed with lust. (St. Thomas II-II, q. 10, a.11)

\section{I ntroduction}

The history of attempts at the regulation of paid sex work is as old as the profession itself. This chapter illustrates this with reference to the analysis made by social historians of the late Middle Ages and the Renaissance in Europe. It points out the basic contradiction in Western thought reflecting the ambiguity of the sexuality as both valued and disdained. Policies of prohibition policies were followed, and sometimes even accompanied by policies of full tolerance, epitomized by the fact that female adultery was much more severely penalized than female prostitution which was defended as necessity of life for men. Reformers hold that abolition of marriage is the only way out of the problem. From a theoretical perspective, this illustrates the process of creating so-called counter-mores that are in fact a functional subsidiary to the official legal rules. Sex-work, unless emancipated, is always regulated as adjacent to market relations. Even if illegal, the sex-work is based on contract, the breach of which is considered as against the intuitive law ruling the domain. And this means that sex-work is the opposite of forced sex, ie rape defined as non-consensual sexual relations.

\section{The Countermores}

Though the hypocrisy demonstrated in various examples has been the subject of sociology from its scientific beginnings, witness for example Pareto's extensive study of derivations, it is the concept of countermores introduced by Lasswell that I want to focus on in my paper. "Countermores are the devant traits that are expected to occur". Laswell, following Sumner's concept of folkways as recurrent patterns of conduct and the reintroduction of mores in sociology, felt it necessary to distinguish between those that are defined as positive and the negative group ("deviant"), adding also the neutral ones classified as "deficiencies" (Lasswell 2013, p. 50). In this classical formulation what is the critical „expectation to happen". Such a formula runs contrary to optimistic theory that only positively conduct is repeated and that everything repetitive becomes a norm. The obvious fact that not only repeated actions are considered just, good and proper by moralists and public opinion at large led social scientists to acknowledge the social existence of negative norms. Norms in social-scientific meaning are patterns of behaviour of varying "normative" character.

\section{Baillyhoc Street Case of 1387}

In the acts of the Parliament of Paris a case recorded in 1387 attracted the attention of the medievalists and continues to serve as the factual point of reference in attempts at reconstructing the French mentality of the period and more particularly the approach to the professional sex work. One needs to consider that on looking into the official royal law of those day one encounters silence broken suddenly by the decree of King St Louis IX who banned prostitution completely, demanding a purge of all areas where sexual traffic was practiced. The attention that this law evoked in the surviving sources as well as the official partial retreat later in new law provide a convincing argument that the abolition of prostitution was considered revolutionary and met with passive resistance on part of the all important segments of $14^{\text {th }}$ century French society (Geremek 1971/2006, 1972, Roussiaud 1984/1997, Dufour 1998) independently of the official declarations. 
Several years after the decree of pious King St Louis three burghers appeared before the Parliament of Paris, Messrs Jacques de Branc aka Jacobin, Philippes Gibier and Guillaume de Nevers as plaintiffs and le chevecier, cure and canon ladies of the church of St Merri "saying that there always had been sex workers (femmes de vie) in the V[B]aillehoc street, but prevost of Paris ordered them to leave, and forbade the owners of the houses at the street to lease". When the second party was convened, the St Merri's church priests and canon ladies "said that king St Louis ordered that such women should no longer stay in honest places and streets and imposed a penalty on the house owners that is the four times the value of the lease money". They said that the street is close to the beautiful and large distinguished streets (belles et grandes rues notables) where many burghers of both genders use to stay as well as the lazy canons and chaplains of the said church.... that many inconveniences happen and many more might happen because if a villain (houllier or ribaud) would kill somebody that would happen close to the church where he might hide himself [NB right of asylum linked with the temples]. The applicants said people walk up to St Merri and to la Verrerie through the beautiful and honest street and that in such honest streets (rues honnetes) these "ladies (femmes folieuses) should not stay" and thus they were ordered to leave and houseowners were forbidden to lease apartments to them". To this and other arguments about "honesty", the plaintiffs answered that "it is expedient that such women are on the public streets and not in the [private] fauburgs; they will make less inconvenience than in the forested streets; [that] the street is narrow and it is good only for such a business (métier)"and that "such delict should be not be committed on a large street. Many other arguments were presented such as the long tradition (these women had been present here "de tout temps"), a decree (the second) of king St Louis, an order of the former prevost of Paris Hugues Aubriot who had in person lustrated all brothel areas in Paris letting some, including Baillyhoc street stay "as it offers a better opportunity to honest people than many other brothels (bourdiaux)". At the end they reminded the court that "it is in the interests of St Merri's church to keep the brothel for the income (les rentes) it brings as it is written (c edit raison scripte) that virorum honestiorum domibus saepe lupanaria exercentur". As for the argument of the clergy that they must walk with the Eucharist through the street the house owners replied that there is another way and added significantly that after all "it is expedient that the brothel shall be close to the church as however much those women are sinning they are not damned and it is expedient that they go from time to time to the church which they will do more if they stay closer to the church than if they are far away" (Felibien 1725, IV:538-539). The lively contest continued and no final judgment was made. Moreover the dispute came back to the court several years later.

\section{Tax-exemption and sex-work}

Medieval theology had the very practical task of interpreting in official doctrine and canons of faith in the face of the hard facts of life. However speculative, theology was very much an applied science, and the consequences of theorizing often had the ultimate sanction of capital punishment not to speak of eternal damnation for the culprits. Keeping this in mind one should not be surprised that questions of sexual behaviour had been examined in detail by scholars who were otherwise discussing the attributes of God and the angels. So not only did a debate on appropriateness and degree of sinfulness develop for various sexual practices, (and continues to the present day) but the question of the moral quality of the money paid for sex is subjected to theological scrutiny. Rossiaud (1984/1997, 134) notes, after Le Goff and Geremek, that in about the year 1200 the canons of Notre Dame Cathedral in Paris had to decide whether to accept the gift of a stained glass window, or vitrail offered by the prostitutes. One of the canons Thomas of Chobham opined that the gift should be rejected if bought from funds acquired through lascivious satisfaction through their work. The iustum pretium, however, based upon proper professional performance and honest (not artificially embellished) bodily presentation is due to someone who performs sex services out of necessity and not for pleasure, and alms 
offered from funds acquired in this way should be accepted. St. Thomas sixty years later opined that it is the condition of the work which is sinful and not the money earned and thus the alms might be accepted by the Church though not the property of unrepenting sex-workers. However in 1358 Pope Innocent VI forbade the taxing sex-workers by his administration in Avignon, while taxing the brothel-keepers was standard procedure in French cities (Roussiaud 1997, 135 n. 24).

A similar problem has been confronted in Poland since the end in 1989 of the statist socialist regime run by the Communists. Legally the problem was on the books all the time before this as selling sex in itself had never been criminalised in Poland. But under state socialism the personal tax system was limited to the small part of the population that was engaged in registered private business, sex-services excluded. One of the major elements of the sudden transformation was the introduction of the general individual taxation based upon personal declaration of income. With rapid development of the sex-business the question of taxing this income emerged and the knowledge about the tax exemption provided by Polish law on all income earned through selling sex services became widely known. The Civil Code of 1964, in Article 58 para 2, states that "legal action contrary to principles of social cohabitation is void". Polish administrative justice had adjudicated several cases in which the claim to such exemption had been rejected by the tax administration. There are general statements like that of the Supreme Administrative Court in Rzeszów on 23th November 1999 (SA/Rz 1066/98) in which we read that "As for the actions that cannot be subject of legally effective contract (...) it refers to such actions as theft, procurement, prostitution [!] i.e. actions that are prohibited as well as actions absolutely void". Let us observe that the Court in one line listed criminal actions like procurement which is penalized by Polish Criminal Code, and the legally void actions of prostitution.

The "legal void" surrounding sex-work had not thus made it immune to official legal intervention while making illegal any official police interest in the sex-work as such in contrast to the "escort agencies" that mushroomed throughout the country since 1987 and introduction of the free market. From time to time one reads about the decisions made by the administrative justice concerning the claims for taxexemption.

One of such land-mark cases involved the woman who had claimed that she bought an apartment for almost 30,000 euros from the earnings made while selling her sex services in UK. The case started with the tax office refraining in 2007 from acceptance of such a claim as the income declared by plaintiff in her annual tax declaration had been of much lower (ca 2,500 euros) value. The tax officer had rejected the claim arguing that the plaintiff had not proved or made probable performance of the said business while in the UK and pointed out that she neither had declared the said earnings to the British revenue service, despite the fact that earnings from sex are taxable income in the UK. The plaintiff appealed then to the administrative court presenting "a dozen or so pictures in which only the plaintiff is shown, two apartment renting receipts from L., air tickets, receipts from the dress boutiques or bank accounts supposedly concerning the transfer of the earnings to her account in Poland". These proofs had been rejected by the first level administrative court in 2014 as insufficient because the witness had not confirmed the performance of sexwork by the plaintiff and this was confirmed by the appellate court. The plaintiff among others made two interesting points: first, in relation to the formal error involved in one of the precedent decisions upholds the position taken by the Constitutional Court that despite the procedural error behind the relevant regulation it should be followed in order "not to unjustly favour the taxpayers not fulfilling their duties against the taxpayers who reliably fulfill their duties" and "to minimize the negative financial consequences for the state i.e. for the all citizens". The relevant regulation obliges tax-payer to pay "penalty" tax for the "unreported income". Secondly, someone who claims the income coming from the legally void activity such 
as sex-work must at least make his/her claim "probable", which was missing in this case.

An interesting example of the research efforts that administrative justice has to undertake in cases of similar character is provided by an earlier verdict of the Regional (Wojewódzki) Administrative Court in Wroclaw pronounced on 23d April 2010 (I SA/Wr 118/10). The material value of the tax-exemption claim was this time much higher. In 2008 the tax officer established the due and unreported taxable income of Ms. J.D. at of value equivalent to about 300,000 euros. The decision was made comparing the value of apartment bought in 2002 (ca 200,000 euros) with nil income declared in this and the preceding years. Since December 2000 the plaintiff stayed in L. in the UK on a student visa transferring in two years almost 380,000 euros on her Polish banking account. Tax officers had not recognized as evidence of the sex-services supposedly practiced in the UK "the printouts of the consort agencies web pages, Xerox copies of the escort ads, witnesses accounts and the statement by the plaintiff" as "even if assuming that the presented evidence concerns the plaintiff (...) there was no evidence that somebody really used the offer and that the plaintiff had received the pay in the declared amount". The Tax Office recognized only that "an offer of sexual services" had been made. But this had not ended the tax office work as the administration agreed with the plaintiff that "it is difficult to demand from the taxpayer to provide the documentation of performing such services" so "it was necessary to undertake deeper analysis of the explanations given by the plaintiff and evidence offered by the witnesses she brought". During this exercise the administration had decided that from the above documents - including the British tabloids - "followed unequivocally that the plaintiff was a prostitute performing exclusive services (not only [!])". However, part of the earnings - according to the analysis - had not been enough proved as coming from the prostitution so it was declared as taxable as "unreported taxable income". The Regional Administrative Court to whom the plaintiff appealed upheld the tax office decision. Ethnographically interesting detail of the judicial verdict deals with the distinction between "exclusive" and "not only exclusive" sex services offered. Accepting the evidence that ca 200,000 GBP were earned through "exclusive" service the court pointed out that justifying the amount of the income earned at one moment while giving the testimony the witness said that she was so busy that "one client was leaving when the next one was coming in" and this could not be considered as "exclusive" highly paid sex service. The plaintiff when starting her sex-work in L. had not yet learned English so the claim to "exclusivity" was at least in the first months also ungrounded. The whole accounting including the "exclusive" and "not only exclusive" parts of the sexual encounters of the plaintiff went much further and ended up in deciding on rejection so the 145,000 GBP paid by the witness $D$. and some other sums acknowledged to be nontaxable as coming from the legally void actions while the remaining 24,520 GBP was taxable as unreported income.

\section{Current Moral Climate}

In three Polish communities - a small town in Upper Silesia (Olesno), another small town in the hills on Polish-Ukrainian border (Lesko) and metropolitan Ursynów ,a district of Warsaw - we asked samples (random in Olesno and quota in Ursynów) in 2015 about the reputational consequences of several controversial types of conduct first if committed by a male, then by a female. This was meant as a way to ascertain the perception of the evaluation standards prevailing in the society. 
TABLE 1

\begin{tabular}{|c|c|c|c|c|c|}
\hline \multicolumn{2}{|c|}{$\begin{array}{l}\text { Does the following way of conduct put one } \\
\text { into a disrepute? }\end{array}$} & \multicolumn{2}{|c|}{ OLESNO $(100 \%=\mathrm{n}=189)$} & \multicolumn{2}{|c|}{$\begin{array}{l}\text { URSYNÓW }(100 \%=n \\
=192)\end{array}$} \\
\hline & & $\begin{array}{l}\text { Male } \\
\text { reputation }\end{array}$ & $\begin{array}{l}\text { Female } \\
\text { reputation }\end{array}$ & $\begin{array}{l}\text { Male } \\
\text { reputation }\end{array}$ & $\begin{array}{l}\text { Female } \\
\text { reputation }\end{array}$ \\
\hline \multirow[t]{4}{*}{ Drunken driving } & Very much & 82 & 90 & 85 & 90 \\
\hline & Somewhat & 10 & 5 & 15 & 10 \\
\hline & Not at all & 8 & 5 & . & . \\
\hline & $100 \%=$ & 183 & 183 & 182 & 182 \\
\hline \multirow[t]{4}{*}{ Getting drunk in a pub } & Very much & 50 & 79 & 55 & 71 \\
\hline & Somewhat & 33 & 12 & 35 & 23 \\
\hline & Not at all & 17 & 9 & 10 & 6 \\
\hline & $100 \%=$ & 182 & 181 & 181 & 181 \\
\hline \multirow{4}{*}{$\begin{array}{l}\text { Premarital cohabitation } \\
\text { with permanent partner }\end{array}$} & Very much & 9 & 13 & 4 & 5 \\
\hline & Somewhat & 17 & 21 & 22 & 26 \\
\hline & Not at all & 74 & 66 & 74 & 69 \\
\hline & $100 \%=$ & 182 & 182 & 181 & 183 \\
\hline \multirow{4}{*}{ Premarital loss of virginity } & Very much & 10 & 15 & 6 & 7 \\
\hline & Somewhat & 12 & 17 & 15 & 21 \\
\hline & Not at all & 78 & 68 & 79 & 72 \\
\hline & $100 \%=$ & 174 & 177 & 179 & 181 \\
\hline \multirow[t]{4}{*}{ Marital infidelity } & Very much & 63 & 76 & 70 & 79 \\
\hline & Somewhat & 26 & 18 & 24 & 18 \\
\hline & Not at all & 11 & 6 & 6 & 3 \\
\hline & $100 \%=$ & 180 & 181 & 179 & 179 \\
\hline \multirow[t]{4}{*}{ Child out of wedlock } & Very much & 16 & 20 & 10 & 12 \\
\hline & Somewhat & 23 & 24 & 25 & 26 \\
\hline & Not at all & 61 & 55 & 66 & 61 \\
\hline & $100 \%=$ & 180 & 181 & 178 & 178 \\
\hline \multirow[t]{4}{*}{ Cross-dressing } & Very much & 67 & 35 & 55 & 21 \\
\hline & Somewhat & 14 & 18 & 16 & 27 \\
\hline & Not at all & 19 & 47 & 30 & 52 \\
\hline & $100 \%=$ & 178 & 179 & 176 & 174 \\
\hline \multirow[t]{4}{*}{ Living of sexual services } & Very much & 72 & 78 & 77 & 76 \\
\hline & Somewhat & 13 & 11 & 13 & 15 \\
\hline & Not at all & 15 & 11 & 10 & 9 \\
\hline & $100 \%=$ & 178 & 179 & 178 & 176 \\
\hline
\end{tabular}




\begin{tabular}{|c|c|c|c|c|c|}
\hline \multirow[t]{4}{*}{ Begging } & Very much & 51 & 46 & 48 & 44 \\
\hline & Somewhat & 30 & 32 & 25 & 29 \\
\hline & Not at all & 18 & 20 & 26 & 27 \\
\hline & $100 \%=$ & 175 & 176 & 177 & 177 \\
\hline \multirow{4}{*}{$\begin{array}{l}\text { Being at spouse’s } \\
\text { maintenance }\end{array}$} & Very much & 32 & 8 & 30 & 7 \\
\hline & Somewhat & 22 & 16 & 25 & 16 \\
\hline & Not at all & 46 & 76 & 45 & 77 \\
\hline & $100 \%=$ & 177 & 181 & 179 & 177 \\
\hline \multirow{4}{*}{$\begin{array}{l}\text { Going to West for work } \\
\text { while leaving small } \\
\text { children with family }\end{array}$} & Very much & 34 & 41 & $\mathrm{X}$ & $\mathrm{X}$ \\
\hline & Somewhat & 19 & 25 & $\mathrm{X}$ & $\mathrm{X}$ \\
\hline & Not at all & 47 & 31 & $\mathrm{X}$ & $\mathrm{X}$ \\
\hline & $100 \%=$ & 181 & 189 & $\mathrm{X}$ & $\mathrm{X}$ \\
\hline \multirow[t]{4}{*}{ Living from smuggling } & Very much & 67 & 67 & 59 & 61 \\
\hline & Somewhat & 17 & 16 & 24 & 25 \\
\hline & Not at all & 17 & 16 & 16 & 13 \\
\hline & $100 \%=$ & 180 & 182 & 177 & 177 \\
\hline \multirow{4}{*}{$\begin{array}{l}\text { Unattending the church } \\
\text { services }\end{array}$} & Very much & 18 & 19 & 7 & 6 \\
\hline & Somewhat & 34 & 26 & 18 & 19 \\
\hline & Not at all & 58 & 55 & 74 & 73 \\
\hline & $100 \%=$ & 189 & 179 & 176 & 176 \\
\hline \multirow[t]{4}{*}{ Public swearing } & Very much & 52 & 65 & 36 & 50 \\
\hline & Somewhat & 33 & 27 & 47 & 38 \\
\hline & Not at all & 15 & 8 & 17 & 12 \\
\hline & $100 \%=$ & 180 & 183 & 177 & 177 \\
\hline \multirow[t]{4}{*}{ Not kicking back } & Very much & 27 & 16 & 18 & 12 \\
\hline & Somewhat & 23 & 15 & 24 & 13 \\
\hline & Not at all & 50 & 68 & 58 & 75 \\
\hline & $100 \%=$ & 177 & 180 & 177 & 177 \\
\hline
\end{tabular}

Table 1. Assessment of behaviours according to the gender of the perpetrator (as \% of those who responded).

Out of 15 examples of conduct included in our small town questionnaire and 14 in the metropolitan area questionnaire, nine had espoused some double standard effect, though of different types. The overall correlations between threats to women's and men's reputation are almost always statistically significant but they differ in strength. Rank order in strength answers our question concerning double standards, the stronger the correlation the gender standards are more alike, the weaker the more different. On the bottom of our list of factors threatening the reputation is living maintained by the spouse. In the middle there are not retaliating the physical assault and cross-dressing, more upward drunken driving, getting drunk in a pub and marital infidelity. All others are close to each other and to the top end of the rank order. I mportantly, here are located all acts with sexual connotation except conjugal fidelity (slightly weaker correlated) and cross-dressing.

Cross-dressing is on our list a strange type of behavior as it is assumed of sexual (at least erotic) character in case of men putting on full female attire or just element. 
Female underwear is the well-known fetishist object that a man may wear secretly. Putting on women's outer dress is more risky though the emergence of the so-called uni-sex dress made such experiments less manifestable unless the skirt, women shoes or wig is used. Though erotic pleasure may be as well attached to men's dress by women, the takeover of trousers by women made the cross-dressing in this direction sexually neutral. So, as for centuries men are censored for female dress while the opposite, obvious still before the World War I, does not hold on anymore.

The second point to be made concerns the relationship between social habitat and normative standards. In both small towns under study the average correlation is lower than in a metropolitan area. In Lesko Mean $r=0.70$, in Olesno Mean $r=0.69$ while in metropolitan Ursynów Mean $R=0.79$. It is not clear in what areas this difference holds but if we divide reputation factors into those with sexual/erotic connotation and the others the clearer picture emerges. In the sexually/erotically connotated cases (3-8) Mean $r$ in Lesko equals 0.73 , in Olesno 0.67 and in Ursynów 0.81 , while for the other factors mean coefficient equal in Lesko 0.69 , in Olesno 0.70 and in metropolitan Ursynów 0.78 . The broadly defined type of reputation factor evidently is thus not related with the different social habitat and concomitant characteristics of its inhabitants. The small town dwellers are on average slightly more prone to use different standards when judging the reputation risk a behavior brings to men and women, in big city the duplicity is weaker.

As for the main focus of our research as presented here we must observe that the reputational costs of sex work are on top of the list independently of the social milieu. There is wide agreement as to the damaging effect of being a sexual worker and this is reflected in that the referring to such activities continue to be one of the most common and most offensive insults and considered as a slander to be actionable in court by those offended (Fuszara 2017).

On the other hand, the effect of sex work on reputation is not unanimously reported by the respondents as about one fourth considers it to be of slight or even (about $10 \%$ ) no damage at all. Thirdly we found that as for the disrepute hazards of sex no gender double standard is being used. The majority considers it damaging independent of the gender of the sex-worker, so it is not related at all to the specifically feminine ideal of carnal chastity. Living on the proceeds of sex is the mode of life that is generally damaging to one's reputation. In that Polish public opinion seems to have reached a high level of congruency - the only large gender differential related to the sexual ways emerges in rating the reputational costs of cross-dressing which in case of women lost its old gender identification character (trousers) in contrast to men considered deviant if caught in women's dress. Getting drunk in the public and public swearing remain non-female ways of behaving while being dependent on the wife is seen as unmanly. So, in sum the double standard continues but it had been lifted off from the sexual arena which is almost equally assessed as damaging or undamaging independent of the gender. The double standard is considered as different judgment by gender but such difference did not appear in our study - the distribution of opinions on the damaging effect of sex work was similar for both genders.

The negative assessment of sex work is not isolated, however, as the absolute majority of respondents consider also smuggling as the damaging to reputation. Most of the respondents also consider begging as damaging one's reputation. This has led me into further orthogonal factor analysis of the correlations between all (15 in the small town and 14 in metropolitan district) the activities under assessment. This revealed that in the small town the significant impact of sex work on reputation were on the same level as begging; in the metropolitan area on the same level as public swearing. In the small town culture prostitution belongs to the category of unworthy jobs, in metropolitan culture it is more the question of good taste and style.

Last remark needs thus to locate the attitudes to the reputational risk of sex-work within the wider context of sexual morality. In the inventory there were five cases of 
widely understood sexual practices that until the present day remain within the domain of the Catholic sexual ethics, that is sexual continence before marriage and the duty of marital fidelity after the union had been concluded. Needless to say, the union itself according to the Catholic Church teaching is sacramental and should be taken before the priest. Of this whole set three components - premarital cohabitation, loss of virginity, having child out of wedlock - visibly lost its normative power for otherwise mostly Catholic Poles while marital fidelity and keeping sex off the commercial exchange retained its normative character for majority of respondents.

\section{Conclusions}

The ambivalence expressed by the negative aura surrounding widely practiced sexual behaviour permeates European culture. It might be due to the demanding ideal of Christian ethics which results in the gap between the sacred law upheld by the clergy and the more tolerant secular official administration of justice. Even then, legal ambivalence is resulting from the unwillingness of the official legal system to recognize sex traffic as a normal part of life and the legal impossibility to escape from the social reality of such trade when a plaintiff arrives to plea openly the right to recognize legally the indecency of the way her/his income was acquired. The French medieval model of tolerance was in this matter less hypocritical then the abolitionist model practiced in Poland after 1952. The medical theory, such as that formulated by Jan of Ludzisko ( ca 1440) concerning the necessity for regular male ejaculation (plus moral condemnation of masturbation) had provided (and as we may reasonably suspect still provides in common sense thinking) basic legitimation of the otherwise illegitimate activity. The conflict between two assessments - religious and pragmatic - continues as we have just seen from the Middle Ages until the present day. Of course, sex traffic and sexual behaviour in general was not the only such area of moral/practical conflict. Studies of gambling - legal and illegal - come immediately in mind. But historically sexwork seems to be connected semiotically with usury and simony. In our view it is not so much a question of sexual morality as a matter of attitude towards money as a common denominator for these areas. The following story illustrates the point. The pastoral Nuer people when coming to work in the large city of Khartoum before the independence of South Sudan were employed in cleaning human waste. They kept the banknotes earned from such work as the "shit money" separately from the other banknotes in order not to pollute the money needed to buy ceremonial marriage cattle (Hutchinson 1996). Money need not be treated as the amoral, universal medium of exchange. Ever since the Old Testament days some money was put under similar scrutiny and this suspicious approach was inherited by Christianity. In its minimal version the sacred should not be sold and the medieval public debate on simony became so heated that it ended up with the Reformation and division of Western European Christianity. Interestingly the sale of secular offices remained normatively neutral until the emergence of the secular ethics of civil service, while in the reformed part of the church the desacralised items had been in general exempt from sacred damnation. The sacramentalization of marriage in the Roman Church led to sacralization of marital procreative sex that is still in direct opposition to the autotelic sexual pleasure. The paid sex - as we have noted - was not damned if done out of life necessity and not for pleasure. It is the combination of pleasure and monetary gain which constitutes the evil of prostitution in the Christian basis of European morality. "Sex money" is as polluting for Christians as "shit money" for the Nuer. The church cannot accept it even if transformed into a stained glass window (vitrail) for Notre-Dame-of-Paris Cathedral except as alms. The "usury money" was also polluting, so the same ordonnance of pious king St. Louis that obliged "folly ladies" to wear special dress also forbade gambling and imposed similar stigma on Jews as "usurers" (unless they forgo the usury) forcing these groups to withdraw to the margin of social life. Jews and Lombard banking came soon back to fill the inevitable void in financial demand as well as the streets of tolerance that channelized the unsatisfied lust. 
The whole story as sketched above interests us as a case of institutionalized hypocrisy that needs to be included in the sociological theory of law. For people brought up in the Petrazyckian theoretical tradition (Podgórecki 1980, Motyka 2006) the obvious reaction to the normative ambivalence implicit in the European approach to commercial sexual interactions would involve reference to the intuitive law (Kurczewski 1976) as understood in the socio-legal theory developed on the Petrazyckian base (Podgórecki 1991). In reaction to the countermores of Lasswell one thinks immediately of Malinowski (1926) and his observation that despite the official non-authoritative law binding the Trobrianders there is counter-law that allows the loving father to care for the well-being of his son who is legally unrelated in contrast to the sister's brother's son who is the only legitimate inheritor under the Trobriand matrilineal rules of succession, or the rules of love magic that allow the adulterer to win a lover and to escape supernatural sanctions.

However I suggest that a more complex theory is needed to embrace the normative ambivalence. Of course, there is unofficial intuitive law that rules the transactions between sexual worker, her/his client, her/his agent ("the pimp") and her/his employer (if any). Pacta sunt servanda is the simplest and most general maxim that holds in these transactions. We have seen that medieval theology elevated it to the discursive level with Thomas of Cobhon discussing and upholding the professional ethic of the prostitutes. When Polish administrative justice is checking the state tax assessment of the sex trade income it is also assuming that the business is run along such principles. Sex transaction is legally void but it is not criminally fraudulent. The popular literature as well as the chronicles of public order agencies are full of examples of quarrels between individual competitors on the street, the illicit or "legally void" character of contact for sexual service makes it also vulnerable as both sides may cheat. In general, the order prevails as the permanent sex job requires good trade reputation that may be damaged by not fulfilling the terms of the oral contract. Here as in any other area of social life the old principle that both Petrazycki and Malinowski observed applies: "Civil law (...) consists then of a body of binding obligations, regarded as a right by one party and acknowledged as a duty by the other, kept in force by a specific mechanism of reciprocity and publicly inherent in the structure of their society" (Malinowski 1926, 58). The expectation of reciprocity in this case is generalized upon the infinite set of potential clients to whom the sex offer is addressed, while a client assumes that he/she is approaching the professional representing the infinite class of sex workers who are interested in continuous demand. Of course, these implicit assumptions in the "exclusive cases" are verbalized as a specific contract between "sponsor" and a "sponsoree" but in general it holds true that "fulfilling what is due to others is a normal, everyday event and it seems obvious" (Petrazycki 1959, I: 302).

But it seems too much of a simplification to oppose intuitive/living law to official law as Podgórecki (1991) does in his theory. The border between the two laws is, like all borders, porous even if the degree of porosity varies. In the case of sex trade the porosity can be seen with the naked eye and the border itself is disappearing. The Parliament of Paris in the 14th century and the Polish Supreme Administrative Court in the 21st century illustrate this well. The royal law is not followed but it is invoked in the dispute between (public) house owners and the clergy as one of the normative facts. The "custom" or rather "tradition" is called on, as well as the reasons of expediency. The judges need to take into account the administrative decisions of the former prevost of the city but should also consider the practical opportunity the church's vicinity offers to the prospect of satisfying the spiritual needs of the sexworkers as "however much those women are sinning they are not damned". Though even if le delit shall inevitably be committed somewhere, and sometimes it needs to be regulated for the good of the clients (the narrow back street is more discreet) and for the general good (sex traffic on large street is more abusive). All these involve normative arguments of mixed nature, some coming from the intuitive-living law, some from the positive State or Church law. Similarly, although consensual adult sex 
traffic is "legally void" the Polish court must deal with its details assuming the unwritten contracts made and fulfilled, offers in the social media not being equivalent to the actual sale of services, accepting the "sponsor"'s testimony. The legal nonbeing is legally acknowledged in its living details.

And this is exactly what we call a legal ambivalence. The laws that are active here are of different character, in fact this a legal bricolage made out of many elements of different character - some official, some unofficial; some intuitive and some positive that is based upon external ("positive") justifications. Whenever such a combination of heterogeneous normative arguments is in use in a debate concerning a particular trouble case we are confronted with legal ambivalence. As is the case with the sex trade, such ambiguity is the inevitable consequence of the institutionalized hypocrisy that surrounds a given problematic (or better: controversially problematized) area of human life practice.

\section{References}

Dufour, F.S.P., 1998. Historia prostytucji II. Trans.: A. Baniukiewicz. Gdansk: Uraeus.

Felibien, M., 1725, Histoire de la ville de Paris. Paris: Desprez and Desessartz.

Fuszara, M., 2017, Honour and reputation in civil courts / Private prosecution. In: J.M. Kurczewski and M. Fuszara, eds., How People Use the Courts. Frankfurtam-Main: Peter Lang, 65-106.

Geremek, B., 1972. Życie codzienne w Paryzu Villona. Warszawa: PIW.

Geremek, B., 2006. The Margins of Society in Late Medieval Paris. Cambridge University Press. (Originally published in 1971).

Hutchinson, S.E., 1996. Nuer Dilemmas: 1996, Coping with Money, War, and the State. Berkeley: University of California Press.

Kurczewski, J., 1976. Due dimensioni del diritto: diritto positive o intuitive e diritto ufficiale o non ufficiale (Two Dimensions of Law: Positive vs Intuitive and Official vs Unofficial). Sociologia del Diritto, 1.

Lasswell, H., and Kaplan, A., 2013. Power and Society: A Framework for Political Inquiry. London: Routledge.

Malinowski, B., 1926. Crime and Custom in Savage Society. New York: Harcourt, Brace and Co.

Motyka, K., 2006. Law and Sociology: The Petrazyckian Perspective. In: M. Freeman, ed., Law and Sociology. Oxford University Press, 119-140.

Petrazycki, L., 1959. Teoria prawa i państwa w związku z teorią moralności. Warszawa: PWN.

Podgórecki, A., 1980. Unrecognized Father of Sociology of Law: Leon Petrazycki. Law and Society Review, 15, 183-202.

Podgórecki, A., 1991. A Sociological Theory of Law. Milan: Giuffré.

Rossiaud, J., 1997. Prostytucja w średniowieczu. Trans.: P. Salwa. Warszawa: PIW. (Originally published in 1984).

The Civil Code, 1964. Polish J ournal of Law [online], no 16 (18) of 1964. Available from: https://supertrans2014.files.wordpress.com/2014/06/the-civil-code.pdf [Accessed 4 December 2018]. 